\title{
Extrusion Technologies in Ensuring Sustainable Development
}

\author{
Alexander R. Volkov ${ }^{1,2, *}$, and Svetlana A. Chernikova ${ }^{1,3,4}$ \\ ${ }^{1}$ Institute of Economics of the Ural Branch of RAS, 29, Moskovskaya St., Ekaterinburg, 620014, \\ Russia \\ ${ }^{2}$ Saint-Petersburg National Research University of Information Technologies, Mechanics and Optics, \\ 11/2, Chaykovskogo street, St. Petersburg, 191187, Russia \\ ${ }^{3}$ Perm State Agro-Technological University named after Academician D.N. Pryanishnikov, 23, \\ Petropavlovskaia St., Perm, 614990, Russia \\ ${ }^{4}$ Perm State University, Perm, 614990, Russia
}

\begin{abstract}
The relevance of the research is environmental management is the basis for natural resources conservation, environmental protection and environmental safety. Meanwhile, it is important to use the best available technologies for neutralization and processing of production and consumption waste in addition to observance of the legal and environmental rules. Waste management of production and consumption is one of the main directions of the transition to a circular economy and the use of low-waste and non-waste production, which has recently been actively demonstrated by developed countries.
\end{abstract}

The main aim of extrusive processing of meat waste is considered. Extrusive processing of waste - an effective solution of problems of rational environmental management as allows to make in addition secondary resources products, thereby realizing the principles of economy of the closed cycle; and considerably to reduce environmental pollution due to refusal of burning and waste disposal of livestock production and the meat-processing enterprises.

Subject, tasks and methods of a research is processing of meat waste which call still biological waste and which are formed, generally in livestock production and at the meat-processing enterprises. One of perspective technologies of high-quality processing of waste is extrusive processing.

Research results confirm that In Russia outdated neutralization and recycling of agro-industrial waste technologies lead to the loss of resources. Moreover they have a significant negative impact on the environment. This article deals with the method of extrusion recycling of meat waste. Extrusion recycling of waste is an effective solution to the environmental management problems, as additionally it allows to produce products from secondary resources, thereby the principles of closed-cycle economy are implemented, and significantly reduce environmental pollution by eliminating the burning and disposal of animal waste and meat processing plants. Thus, use of extrusive technologies will allow not only to make waste products, to get additional profit, but also to prevent

\footnotetext{
* Corresponding author : volkovra@yahoo.com
} 
pollution of air, water and land resources harmful substances, providing thereby rational environmental management, and will form a basis of transition to circular economy which formation is impossible without environmental safety.

\section{Introduction}

The current state of the environment demands essentially new approach to implementation of economic activity. Rational environmental management which examples are is necessary: use of low-waste and waste-free technologies, introduction of biological methods of pest control of agriculture, creation of environmentally friendly types of fuel, improvement of technologies of production and transportation of natural raw materials. Rational environmental management ensures environmental safety, effective use of natural resources, improvement of quality of life of the population and, finally, will contribute to sustainable development. For achievement of the goals of sustainable development development of the agrarian sector of economy as elimination of hunger and production of food are the most important problems of worthy existence of mankind is especially important. However, increase in production of food, improvement of quality increase the volume of waste by their production. Therefore there is a problem of reduction of waste, processing and their reuse. It is necessary to develop an agrarian complex not only in the direction of increase in cost efficiency, but also ecological expediency. At the same time one of the major tasks facing an agrarian complex is processing of meat waste which are formed in livestock farms and at the meat-processing enterprises. Activity of agro-industrial complex as well as all subjects of the economic relations, has to conform to requirements of the legislation in the sphere of environmental protection. However, current situation with education and recycling of agro-industrial complex leads to inevitable degradation of natural systems and poses a real threat to health of the population. Today the Russian Federation faces global environmental problems of education and processing of waste [8]. The modern stage of development of agriculture is characterized by strengthening of the technological processes aimed, first of all, at improvement of quality and expansion of the range of the final products, creating a large number of waste. Agricultural waste is divided into waste of crop production and livestock production. Livestock waste is carcasses of the animals who fell from a case, the discarded animals and birds, waste from slaughter. In this article, speaking about meat waste, we mean the livestock waste and waste of the meat industry formed in the course of processing of products of livestock production. Meat waste constitutes big danger to the environment as their processing and neutralization in 2017 were 31.7\% according to Federal State Statistics Service of the Russian Federation [15]. The use of sections to divide the text of the paper is optional and left as a decision for the author. Where the author wishes to divide the paper into sections the formatting shown in Table 2 should be used.

\section{Subject, tasks and methods of a research}

The address with waste in the Russian Federation is only formed today - need of return of industrial and consumption waste to processing and reproduction is more and more realized. For the last three years the annual volume of waste increased almost by one and a half times, and in 2017 in the Russian Federation the record number of waste - 6221 million tons was formed [15]. Structure of waste in 2017: 0.29\% are waste of the I-III hazard classes which are extremely dangerous and contain extremely harmful substances; $1.46 \%$ are the waste of the IV hazard class, classification of waste constituting small danger to the 
environment which can be processed again; 98.25\% are waste of the V hazard class, that waste classification of which bears the lowest degree of danger.

By economic tools in the system of the address with waste creation and formation optimum calculation of cost on temporary placement and recycling, the established payment for burial which in turn renders ecological damage is meant. At this present stage tariffs are so small that do inefficient a recycling, that is processing of waste; lead to unprofitable work of the waste-processing companies; there is no minimization of negative impact on the environment and prevention of formation of waste; there is no stimulation implementation of technologies of obtaining energy from use of waste; and also organization of the low-waste and waste-free enterprises [13]. Also improvement of the existing administrative methods of influence on the address with waste, strengthening of control of respect for legislative rules, standards and the bans on causing ecological damage is required. According to «Bases of state policy in the field of ecological development of the Russian Federation until 2030» at the present stage the main direction is creation of conditions for minimization of the waste and the stage-by-stage technological modernization which is including introduction of the ban on waste disposal, did not undergo sorting and processing [4]. In a total amount of industrial and consumption waste, according to Federal State Statistics Service of the Russian Federation, agriculture makes 41.5 million tons, that is $0.67 \%$; at the same time only $78.07 \%$ of waste (Table 1$)$ [14, 15] are used and neutralized. Data of the state statistics are provided in a section «use and neutralization» of waste in one line, and different technologies and concepts are put into practice: «processing», «utilization» and «neutralization». Therefore it is difficult to analyze data specifically by separate types of waste with necessary extent of specification [18].

Table 1. Formation, use and neutralization of industrial and consumption waste in the Russian Federation

\begin{tabular}{|c|c|c|c|c|}
\hline Indicator & 2015 year & 2016 year & 2017 year & 2018 year \\
\hline \multicolumn{5}{|l|}{ Waste - all: } \\
\hline - volume of formation, millions tons & 5168 & 5060 & 5441 & 6221 \\
\hline - chain growth rates of formation, $\%$ & - & $-2,1$ & 7,5 & 14,3 \\
\hline $\begin{array}{l}\text { - volume of use and neutralization, } \\
\text { millions tons }\end{array}$ & 2357,2 & 2685,1 & 3243,7 & 3264,6 \\
\hline $\begin{array}{c}\text { - chain growth rates of use and } \\
\text { neutralization, \% }\end{array}$ & - & 13,91 & 20,8 & 0,64 \\
\hline \multicolumn{5}{|l|}{$\begin{array}{l}\text { Including agriculture, hunting and } \\
\text { forestry, millions tons: }\end{array}$} \\
\hline - volume of formation, millions tons & 43,1 & 45,8 & 49,2 & 41,5 \\
\hline - chain growth rates of formation, $\%$ & 11,5 & 6,2 & 7,4 & $-15,6$ \\
\hline $\begin{array}{l}\text { - volume of use and neutralization, } \\
\text { millions tons }\end{array}$ & 33,6 & 38 & 42,1 & 32,4 \\
\hline $\begin{array}{c}\text { - chain growth rates of use and } \\
\text { neutralization, \% }\end{array}$ & - & 13,1 & 10,7 & $-23,04$ \\
\hline
\end{tabular}

Despite the small specific weight, waste of agriculture are of great importance. First, they belong to the $\mathrm{V}$ hazard class and can be completely processed for receiving fertilizers, biofuel, energy, forages and feed additives. But at the enterprises of the Russian Federation there is practically no useful use of waste of agriculture, that is economic losses take place. And secondly, waste of livestock production and the meat industry have very strong negative impact on the environment. The used methods of neutralization of meat waste - 
burial and burning - are economically inefficient and lead to exhaustion of natural resources. Development new, modernization and even implementation of the existing technologies of processing of waste demand long ago considerable financial expenses and certain organizational changes. But such approach allows to speak not about neutralization, and about waste management. In this article an object of research is processing of meat waste which call still biological waste and which are formed, generally in livestock production and at the meat-processing enterprises. One of perspective technologies of highquality processing of waste is extrusive processing [20]. The extrusive line of processing of waste is used for creation and realization of waste-free and effective production of products with high properties of food, fodder and technical appointment. Extrusive processing (in translation from Latin extrudo - expression) - represents continuous process which consists in hydromechanical and heat treatment of raw materials and receiving a new product through the forming tool (die). Extrusive technologies are widely used by production of products from plastic, various snacks, pelmeni, ice cream [26, 28]. Types of extrusion are presented in Table 2.

Table 2. Types of extrusion

\begin{tabular}{|c|c|c|}
\hline Cold extrusion & Warm extrusion & Hot extrusion \\
\hline $\begin{array}{c}\text { Mechanical change of } \\
\text { material owing to its slow } \\
\text { movement under strong } \\
\text { pressure and formation of the } \\
\text { new set forms. }\end{array}$ & $\begin{array}{c}\text { A small amount of initial dry } \\
\text { raw materials with a certain } \\
\text { amount of water is exposed to } \\
\text { thermal I influence; the } \\
\text { received product has the small } \\
\text { size, density and plasticity }\end{array}$ & $\begin{array}{c}\text { At the expense of the maximum } \\
\text { speed and pressure transition of } \\
\text { mechanical energy to thermal is } \\
\text { carried out; the moisture share in } \\
\text { raw materials reaches 15-20\%, } \\
\text { and temperature exceeds } 120 \\
\text { degrees Celsius. }\end{array}$ \\
\hline
\end{tabular}

For processing of meat waste it is the most expedient to use extrusive technology which is carried out by method of hot extrusion. The extrusive line of processing of solid waste of meat production allows to perform several operations with raw materials at the same time in one car (extruder) [25]. Formation of a new product happens for the short period of time and processes are carried out by method of hot extrusion: mixing, compression, sterilization and heating. This method of processing of waste of meat production gives an opportunity to produce the quality food completely ready to the use (compound feed for cattle, sterns for pets) $[1,2]$. It is necessary to emphasize that extrusive lines of processing of waste create products with adjustable nutrition, biological and power value. There is an opportunity to change structure and to make products with the increased protein content, mineral substances and vitamins which play an important role in food of animals [5]. Short time of extrusion does not cause intensive destruction of biological structure, keeping the greatest possible amount of vitamins and useful substances, but at the same time during processing there is a destruction of the enzymes having negative effect on an organism of an animal. The extrusive line when processing solid meat waste keeps high sanitary and epidemiologic requirements to a product: elimination of bacteria of family of enterobakteriya, not sporiferous bacteria, such as salmonellas that considerably increases a period of storage of forages $[3,6]$.

\section{Results of a research}

Due to the adoption in 2014 of the Federal law «About Industrial and Consumption Waste» in the Russian Federation essential measures for formation of an effective ecological system of the address with waste began to be undertaken [4]. Nevertheless, burial of meat waste leads to pollution of sewage, degradation of soil layers and does harm to a natural ecosystem. In 20175.44 million tons of waste of the meat industry [15, 16] were saved up 
and if to consider a large number of unauthorized dumps, these indicators can be several times more. Experts consider that now in the Russian Federation no more than $20 \%$ of meat waste are processed $[7,9,10]$. And in the USSR successfully were engaged in processing of meat waste in an extrusion method. At each enterprise of the meat industry there were shops on production of meat and bone meal and production of forages for cattle. At the moment the technology of extruding of waste of the meat industry is widely used in the European countries, the leading producer of lines of extruding is China, but also in the Russian Federation there are plants which are releasing such lines [19, 29].

The extrusive line of processing of waste of meat production promotes formation and functioning of processes of waste-free production (Fig. 1). Initial raw materials are solid meat waste which is crushed in the crusher and are sifted for receiving particles up to 0.8 $\mathrm{cm}$ in size. The size of raw materials and speed of its giving in a zone of reception of an extruder influence compression saturation in the screw mechanism. At the same time $30 \%$ more nutrients remain, than at warm extrusion as the screw mechanism contains the spiral basis in the mechanism and reach the required pressure for extrusion implementation. Heating of raw materials due to its saturated consolidation and speed of increase of pressure in the course of extrusive processing distributes the moisture which is contained in raw materials then there is a sharp transition of substance from a damp state in more porous. The last stage of extrusive processing of meat waste is an exit of a ready-made product from dies. Raw materials heat up to 200 degrees Celsius, pressure at the time of heating varies from 2.5 to $4 \mathrm{MPas}$, the processed material is in an extruder less than 1 minute that increases capacity. Such technological line of processing of solid meat waste has a possibility of design of a product with any compounding. The production cycle consists of mixing of raw materials in a certain proportion with filler, heating to 200 degrees Celsius, crushing, extrusion of mix, cooling $[17,18]$.

The scheme of work of an extruder when processing waste is submitted in the drawing. Initial raw materials from screw 1 come to bunker 2, then to a material cylinder 3 in which raw materials are structured; then the rotating material cylinder is taken a worm 13 and arrives to transportation of the forming cylinder, this cycle is determined by position 4, 12 and 21. Initial raw materials in the first cycle which is feeding for a zone of an extruder 11 become soft and are transformed to a stopper form. In a compression zone the 12th raw materials are heated to the maximum temperature which is regulated depending on availability of nutrients of a product. At a stage of dispensing 5 there is an intensive machining, and these raw materials pass a formation cycle in an extruder head. Further the cycle of thermal influence, cooling with water and heating of raw materials then there is a transportation in an extruder on a material cylinder in which zonal ring heaters 5 with the cooling mechanisms are installed is carried out; the interval between a cylinder close and a loading opening which on channels 4 is cooled with water at the same time control of temperature is exercised in the established temperature regulators 6 . The line of extrusive processing, as a rule, provides internal cooling with the water pumped and which is taken away via device 10 . The extruder receives rotary motions from the electromechanical drive consisting of the engine connected to power supply 12, having the constant or variable stream of current and the mechanism intended for the reducing transmission of energy 9. During transformation of energy there is an axial force which, during transformation affects an extruder during, the return to transportation of mass of fusion which influences and is perceived on the design uniting the case and an element of the bearing, called by bearing hub 11. These working mechanisms of the extrusive line are created in block 8 . 


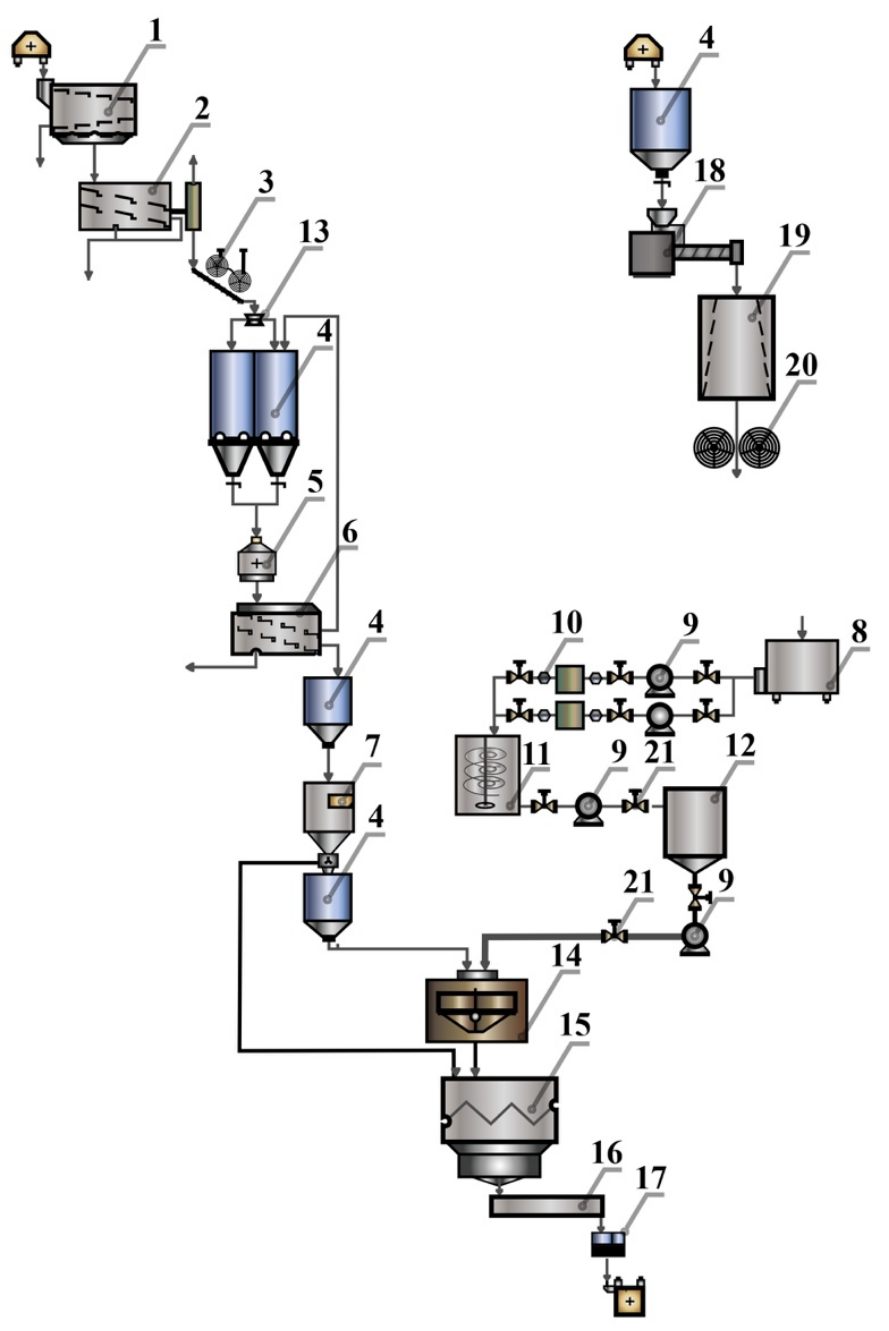

Fig. 1. Scheme of an extruder

The received product from meat waste - proteinaceous feed additive - has the following characteristics: quantity of a protein - 14 - 20\% (depending on a type of the processed waste and vegetable filler); the high biological value promoting comprehensibility (about $90 \%$ ); the digested energy of a forage for restoration of power expenses contains - 290 - $310 \mathrm{kcal}$ in $100 \mathrm{~g}$ of nutrients; bacterial purity - no more than 20 thousand units (at norm of 500 thousand units); the humidity - is not higher than 14\%; a long period of storage — no more than 12 months. The technology allows to add operation of introduction of vitamin supplements for receiving the full-fledged balanced forages with a long period of storage [2, 11]. Experts consider that extruded forages it is better, than granulated [7, 29]. Use of extrusive technologies of processing of meat waste allows to increase production efficiency due to waste management; to create more intensive production; to lower energy consumption (besides the electric power for ensuring technological process other energy carriers are not used: gas, steam, hot water); to lower labor expenses; to increase extent of use of raw materials; to improve comprehensibility of products; to minimize a microbiological contamination of products; and also to reduce environmental pollution, ground waters, there are no emissions in the atmosphere, drains and secondary waste [21, 
27]. It is necessary to cancel that extruder cost with model of hotline of extruding is enough bike, but potentially possible revenues of the organizations from use of extrusive technologies for processing of meat waste can be comparable with income from realization of the main products of production [12].

\section{Business case}

In modern conditions it is necessary to introduce waste-free, low-waste and resource-saving technologies. When choosing this or that technology in agro-industrial complex it is necessary to consider features of the morphological and chemical composition of these raw materials depending on a type of the processed raw materials, existence of technical means and a possibility of use and selling of the received products [24].

The purpose of the project is processing of waste of agro-industrial complex and production of a dry feed of a price budget segment for dogs and cats. These forages have orientation to wide target audience; providing the main functions of food of animals, they are not medical or intended for strictly certain breed, are intended for the balanced daily food. Planned targets of production are given in Table 3.

Table 3. Planned targets of production

\begin{tabular}{|c|c|c|c|c|}
\hline Product & $\begin{array}{c}\text { Average } \\
\text { planned sales } \\
\text { volume }\end{array}$ & $\begin{array}{c}\text { Price, } \\
\text { rub. }\end{array}$ & Revenue, rub. & $\begin{array}{c}\text { Variable costs, } \\
\text { rub. }\end{array}$ \\
\hline Dog food (till 1 year) & 6000 & 81 & 486000 & 138000 \\
\hline $\begin{array}{c}\text { Dog food (1 years are } \\
\text { more senior) }\end{array}$ & 15000 & 71 & 1065000 & 255000 \\
\hline Cat food (till 1 year) & 5000 & 102 & 510000 & 145000 \\
\hline $\begin{array}{c}\text { Cat food (1 years are } \\
\text { more senior) }\end{array}$ & 10000 & 93 & 930000 & 250000 \\
\hline Result: & 36000 & 347 & 2991000 & 788000 \\
\hline
\end{tabular}

In general it is possible to allocate two main groups of goods - dog food and cat food. In each of these groups two subgroups on age of animals - about one year are allocated and the years differing with structure are more senior. For young cats and dogs forages with the vitamin raised by the contents and higher comprehensibility are required. In this regard and also with that factor that they have considerably smaller sales volume, a little higher trade margin on them is supposed [22, 23].

Table 4. Investment expenses

\begin{tabular}{|c|c|}
\hline Name & Sum, rub. \\
\hline \multicolumn{2}{|c|}{ Real estate } \\
\hline Equipment of a warehouse and office & 100000 \\
\hline \multicolumn{2}{|c|}{ Equipment } \\
\hline Set of the production equipment & 13930000 \\
\hline Car & 400000 \\
\hline \multicolumn{2}{|c|}{ Intangible asset } \\
\hline Development of a compounding & 300000 \\
\hline Development of the website & 100000 \\
\hline
\end{tabular}


However the project has no time limit. In the financial plan investment expenses, variable and constant expenses, a tax and credit obligations are considered. The main direction of investment is acquisition of the production line which cost is 13.93 million rubles. The cost of the light truck for delivery of goods to clients is 400 thousand rubles. The main investment in intangible assets - development of own compounding of a forage which will cost 300 thousand rubles. Depreciation of fixed assets is calculated by a linear method for the term of 10 years (Table 4). Integrated indicators of efficiency of the project are given in Table 5 .

Table 5. Integrated indicators of efficiency

\begin{tabular}{|c|c|c|c|}
\hline Indicator & $\begin{array}{c}\text { At } \\
\text { implementation } \\
\text { of the project }\end{array}$ & $\begin{array}{l}\text { At refusal of } \\
\text { the project }\end{array}$ & $\begin{array}{l}\text { Incremental } \\
\text { stream }\end{array}$ \\
\hline Nominal yield (NY), \% & \multicolumn{3}{|c|}{$17,42 \%$} \\
\hline Net present value (NPV), rub. & 21237022,9 & 3919 495,24 & $\begin{array}{l}17131 \\
295,95\end{array}$ \\
\hline Internal rate of return (IRR), \% & $76,89 \%$ & $11,78 \%$ & $68,44 \%$ \\
\hline Modified internal rate of return (MIRR), \% & $31,28 \%$ & $3,17 \%$ & $29,15 \%$ \\
\hline Profitability, \% & $117,51 \%$ & $90,24 \%$ & $128,39 \%$ \\
\hline $\begin{array}{c}\text { Payback period of an investment project, } \\
\text { year }\end{array}$ & 4,43 & - & 18,29 \\
\hline
\end{tabular}

\section{Conclusion}

Rational environmental management means interrelation of two types of activity: ecological activity which leads to reasonable consumption of natural resources and implementation of the actions directed to restoration of the environment, and economic activity which leads to negative consequences and is followed by exhaustion of natural resources. For the Russian Federation the problem considered in article is relevant in view of big formation of waste which lead to the corresponding pressure upon natural resources and an ecological situation, growth of indicators of total volume of formation of waste and significantly the exceeding parameters characteristic of the developed foreign countries. Processing of waste of the meat industry for the purpose of creation of products with new structure, biological and consumer properties allows to carry out economy of raw material resources, provides decrease in costs for raw materials, reduces expenses, reduces negative impact on the environment and is an example of economy of the closed cycle. The expediency of use of extrusive technologies for processing of meat waste is caused by environmental and cost efficiency of a method of hot extrusion. Processing of meat waste also significantly influences development of waste-free production and transition to circular economy which is based on responsible use of resources according to economic, ecological and social reasons and ensuring sustainable development. Thus, use of extrusive technologies will allow not only to make waste products, to get additional profit, but also to prevent pollution of air, water and land resources harmful substances, providing thereby rational environmental management, and will form a basis of transition to circular economy which formation is impossible without environmental safety. 


\section{References}

1. Braginec, S. V. (2016). Tekhnologicheskij modul' proizvodstva ehkstrudirovannogo kombikorma s vklyucheniem rastitel'noj massy. Tekhnika i oborudovanie dlya sela, № 4, pp. 26 - 28. (in Russian).

2. Garzanov, A. L. i Kapustin, S. V. (2011). Ekstruzionnaya pererabotka biologicheskih othodov v korma. Myasnaya industriya, № 9, pp. 84-86. (in Russian).

3. Gosudarstvennaya Duma (2014). Federal'nyj zakon ot 29.12.2014 № 458-FZ «O vnesenii izmenenij v Federal'nyj zakon «Ob othodah proizvodstva i potrebleniya», otdel'nye zakonodatel'nye akty Rossijskoj Federacii i priznanii utrativshimi silu otdel'nyh zakonodatel'nyh aktov (polozhenij zakonodatel'nyh aktov) Rossijskoj Federacii».[About Introduction of Amendments to the Federal Law «About Industrial and Consumption Waste», Separate Acts of the Russian Federation and Recognition Become Invalid for Separate Acts (Provisions of Acts) of the Russian Federation] (in Russian).

4. Gosudarstvennaya Duma (2014). Federal'nyj zakon ot 21.07.2014 № 219 FZ «O vnesenii izmenenij v Federal'nyj zakon «Ob ohrane okruzhayushchej sredy» i otdel'nye zakonodatel'nye akty Rossijskoj Federacii; osnovy gosudarstvennoj politiki v oblasti ehkologicheskogo razvitiya Rossijskoj Federacii na period do 2030 goda: utv. Prezidentom Rossijskoj Federacii 30.04.2012. (in Russian).

5. Epifanova, D. (2018). Razdel'nyj sbor - klyuchevoj faktor razvitiya pererabotki TKO. [Separate collecting - a key factor of development of processing] V: IX Mezhdunarodnyj forum «Ekologiya», Moskva: ANO «Obshchestvennyj forum «Ekologiya» (in Russian).

6. Zverev, A. I. (1988). EHkstruzionnye tekhnologii i povyshenie ego produktivnogo dejstviya. [Extrusive technologies and increase in its productive action] Stern from waste of agrarian and industrial complex] V: nauchno-tekhnicheskaya konferenciya: Korma iz othodov APK, Zaporozh'e: pp. 17-18. (in Russian).

7. Kadyrov, D., Garzanov, A. i Plitman, V. (2008). Ekstruzionnaya pererabotka biologicheskih othodov v korma. Pticevodstvo. № 7, pp. 51-54. (in Russian).

8. Kasil'yas, D. (2017). Kak nauka cherpaet vdohnovenie u prirody. [online] Biomimikriya. https://www.metronews.ru/novosti/world/reviews/biomimikriya-kak-nauka-cherpaetvdohnovenie-u-prirody 1151276 [Last accessed 10.11.2018]. (in Russian).

9. Kas'yanov, G. I., Semenov, G. V. i Grickih, V. A. i Troyanova T. L. (2017). Tekhnologii pishchevyh proizvodstv. Moskva: Izdatel'stvo YUrajt, 113 p. (in Russian).

10. Kochetov, O. S. (2013). Tekhnologicheskaya liniya pererabotki zhirosoderzhashchih othodov. [Technological line of processing of fat-containing waste] Patent of the Russian Federation for invention] Patent № 2487925. (in Russian).

11. Kraus S. V. (2004). Sovershenstvovanie tekhnologii ehkstruzionnoj pererabotki krahmalsoderzhashchego zernovogo syr'ya. [Improvement of technology of extrusive processing of starch-containing grain raw materials] d-r tekhn. nauk. Moskovskij gosudarstvennyj universitet pishchevyh tekhnologij. (in Russian).

12. O korme (2017). Pererabotka pishchevyh othodov v korma [online] Dostupno po ssylke: https://okorme.ru/korm/pererabotka-picshevyh-othodov-v-korma.html [Last accessed 14.01.2019]. (in Russian).

13. Pahomova, N. V., Rihter, K. K. i Vetrova, M. A. Perekhod k cirkulyarnoj ekonomike i zamknutym cepyam postavok kak faktor ustojchivogo razvitiya. Vestnik SPbGU. Ekonomika. 2017. T. 33. Vyp. 2. S. 244-268. DOI: 10.21638/11701/spbu05.2017.203. (in Russian). 
14. SPARK (2018). Informacionnyj resurs statistiki. [online] http://www.spark-interfax.ru [Last accessed 10.11.2018]. (in Russian).

15. Federal'naya sluzhba gosudarstvennoj statistiki (2017). Statisticheskij sbornik «Ohrana okruzhayushchej sredy v Rossii». [online] http://www.gks.ru/bgd/regl/b14_54/Main.htm [Last accessed 10.10.2019]. (in Russian).

16. Federal'naya sluzhby gosudarstvennoj statistiki (2017). Central'naya baza statisticheskih dannyh. [online] http://www.gks.ru/dbscripts. [Last accessed 10.10.2018]. (in Russian).

17. Horenzhij, N. V. (2014). Issledovanie processa ehkstrudirovaniya kombikormov s soderzhaniem vlazhnyh kormovyh trav. Zernovye produkty i kombikorma, № 2, pp. 32 - 36. (in Russian).

18. Yr'ev, V. P. (1991). Fiziko-himicheskie osnovy polucheniya ehkstruzionnyh produktov na osnove rastitel'nogo syr'ya. Vestnik sel'skohozyajstvennoj nauki, № 12, pp. 43 - 51. (in Russian).

19. Amelia, L. (2009). Initiating automotive component reuse in Malaysia. Journal of Cleaner Production. Vol. 17, issue 17, pp. 1572-1579.

20. Ioannidou, A. Zabaniotou (2007). Agricultural residues as precursors for activated carbon production - a review, Renew. Sustain. Energy Rev.

21. Veum T. L., Serrano X., Hsieh F. H., Twin or single screw extrusion of raw soybeans and preconditioned soybean meal and corn as individual ingredients or as cornsoybean product blends in diets for weanling swine // Journal of Animal Science. 2017. - P. 95.

22. Hsieh F. Manufacture of Meat Analogues Through High Moisture Extrusion. // Journal Module in Food Science. - 2016. - P. 211-217.

23. Alam M.S., Kaur J, Khaira H., Gupta K. Extrusion and Extruded Products: Changes in Quality Attributes as Affected by Extrusion Process Parameters - A Review // Critical Reviews in Food Science and Nutrition. - 2016.- P. 445.

24. Krintiras G.A., Göbel J., Stefanidis G.D. Production of structured soy-based meat analogues using simple shear and heat in a Couette Cell. // Journal of Food Engineering. - 2015. - P. 160-194.

25. Li D. Proteins from land plants - Potential resources for human nutrition and food security. // Trends in Food Science \& Technology. - 2013. - P. 25-42.

26. Stepycheva N.V., Makarov S.V., Kucherenko P.N. Secondary material resources of oil-producing plants. // Russian Journal of General Chemistry. - 2012. - P. 969-972.

27. Zhang J., Liu L., Syed S.H., Wang R., Changes in conformation and quality of vegetable protein during texturization process by extrusion. // Critical Reviews in Food Science and Nutrition. - 2018. - P. 1-14.

28. Dutner J., Mines P., Anderson A. Irrigation trends. // American Association of Endodontists members.- 2017. - P. 37-40.

29. Batova, T. N.; Volkov, A. R.; Pavlova, E. A. Extrusion processing of wastes in the closed cycle economy (in Russian) // Research Journal of NIU ITMO. Economics and ecological management series. - 2019. - №. 2. 